\title{
The Present Situation and Prospects of Solar Photovoltaic Power Generation in China
}

\author{
Mali Chang \\ Department of Economics and Management \\ North China Electric Power University \\ Baoding,China \\ 1004944209@qq.com
}

\begin{abstract}
At present, with the rapid development of economy all over the world, the world's energy is in the condition of shortage. At the same time, there is a series of environmental pollution problems.At present,countries advocate the sustainable development all over the world, people hope to have a clean new energy instead of fossil energy limited. Solar energy is one of the most important renewable energy, has long been the attention of people. Solar photovoltaic technology has developed rapidly in recent years in China. through the analysis of the the necessity of solar photovoltaic power generation, the development course and the problems in the development of Solar photovoltaic technology, this article has discussed the applications of Solar photovoltaic power generation in China.I Hope that the applications of solar energy photovoltaic power generation technology can alleviate our dependence on fossil fuels, and ease the problems of environmental pollution in our country as well.
\end{abstract}

Keywords-New energy; Solar photovoltaic technology; power generation; development; applications.

\section{THE NECESSITY OF THE DEVELOPMENT OF SOLAR PHOTOVOLTAIC TECHNOLOGY}

\section{A. the requirements of environmental protection}

Environmental pollution is serious in China, the most serious are air pollution and water pollution. At present our country has the air pollution index of the sulfur dioxide, nitrogen oxides, SPM, the main source of air pollutants are fuel combustion, car tail gas and industrial waste gas, solid waste treatment and so on, according to the composition of atmospheric pollutants and fuel properties, air pollution can be divided into coal-smoke pollution, oil pollution, hybrid pollution and pollution of special type.In the energy structure of China ,coal accounts for more than $70 \%$ of all energy, but the coal utilization rate is only about $30 \%$, and the main types of air pollution in our country is coalsmoke pollution. The combustion of coal has caused severe fog haze, for technology reason, it's hard to remove impurities such as sulfur from coal, resulting the release of coal combustion gas becomes a major cause of the haze. So for the protection of environment and economic sustainable development, we need to look for clean energy.

B. the advantages of development of solar photovoltaic technology
There are abundant solar energy resources on the earth, which are inexhaustible. The energy of the earth's solar is 6000 times greater than the energy for human being needed. And solar energy are widely distributed on the earth, as long as there is light, solar photovoltaic power generation system can be used, which is not restricted by factors such as geographical, altitude. Solar photovoltaic power generation process is simple, no mechanical moving parts,no fuel consumption, no greenhouse gas emissions, no noise and no pollution. And, therefore, compared with wind power, biomass power and nuclear power,photovoltaic power generation is a renewable energy power generation technology of sustainable development of the most ideal characteristics (one of the most abundant resources and clean power generation process).According to the goal put forward by " twelfth five-year "renewable energy development plan, China's solar rooftop installations scale will reach 10 times of the the existing size next five years.

\section{C. the impact of the world's energy crisis}

Under the condition of high-speed growth of industrialization and urbanization, in the face of growing demand for energy, we need to find other renewable energy instead of oil, coal energy . According to the BP Energy Outlook 2035, we can know the status of nonfossil Energy in Energy structure of the world is more and more important.

\section{Share of world power generation}

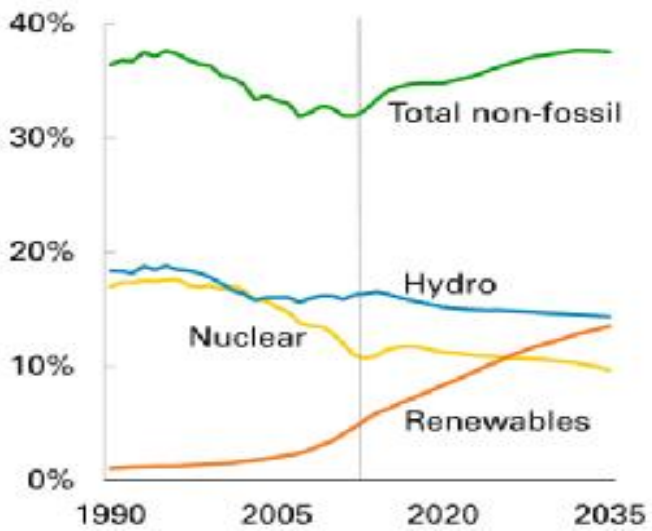

Figure 1.Share of world power generation 
As we can see in the Fig .1, non-fossil energy is expected to reach $40 \%$ share in the world the power generation by 2035 , the new energy will reach $15 \%$ by 2015.

\section{Renewables growth 2013 to 2035}

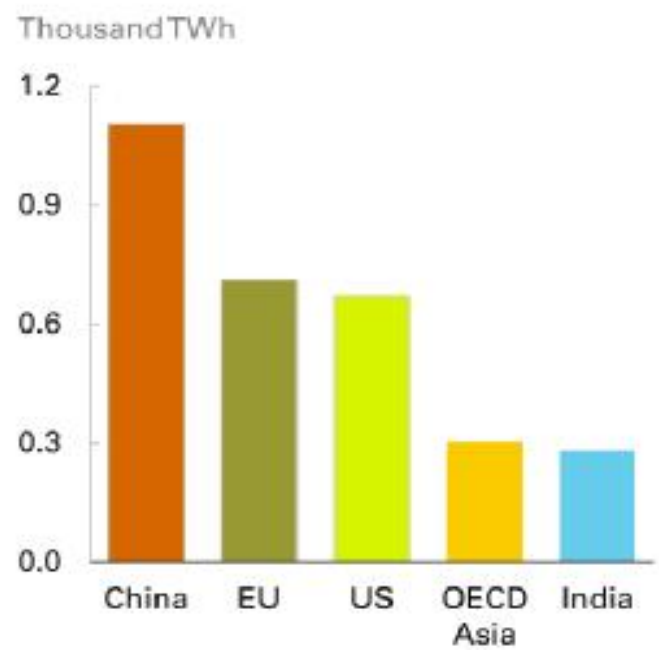

Figure 2.Renewables growth 2013 to 2035

As we can see in the Fig .2, it is predicted that it may be 1.2 thousand TWH in China by 2035.

Inputs to power in China

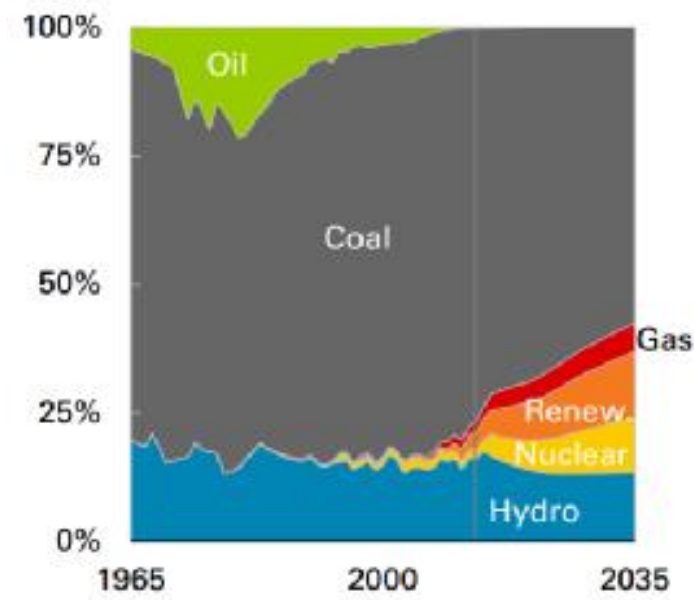

Figure 3.Inputs to power in China

As we can see in the Fig .3, in China's energy structure, new energy has a growth trend, although the proportion is still relatively small.According to the Chinese government has formulated "twelfth five-year" energy planning, by 2015 China's total energy consumption will be controlled around 4.1 billion toe, the proportion of non-fossil energy in primary energy consumption will reach $11.4 \%$, which may be reached $15 \%$ by 2020 . Therefore, our country is in a big demand for new energy.

\section{INTRODUCTION OF PHOTOVOLTAIC POWER GENERATION}

Photovoltaic power generation system is divided into off-grid Photovoltaic system and grid photovoltaic system.

A. off-grid Photovoltaic system

Off-grid Photovoltaic system is mainly composed of solar modules, controllers, batteries, if the power is provided for ac load,the ac inverter is also needed. Off-grid photovoltaic power station includes villages power supply system in the remote area, solar household power supply system, signal power, cathodic protection solar street lamp and so on.

\section{B. grid photovoltaic system}

Grid photovoltaic power generation has centralized large type and scattered small type. Centralized large grid photovoltaic power plants are generally national power plants, the main characteristic is the power generation can be directly transported to the power grid, the power grid make unified deployment to users. But this power plant need big investment, long construction period and plenty of area,so the development prospect is bad. While distributed grid photovoltaic, especially photovoltaic building integrated photovoltaic power generation, because of advantages of small investment, quick construction, cover a small area and policy support, is the mainstream of the grid photovoltaic power generation.

\section{THE DEVELOPMENT OF SOLAR PHOTOVOLTAIC POWER GENERATION IN CHINA}

Since 2010, China's photovoltaic power generation has entered the track of rapid development.by the end of 2013, the national photovoltaic grid capacity is 19.42 million $\mathrm{kW}$, ranking second in the world. Among them, the ground station'capacity is 16.32 million $\mathrm{kW}$ (about $84 \%$ ), in which $77 \%$ is distributed in the northwest region. Distributed photovoltaic'capacity is 3.1 million $\mathrm{kW}$ (about $16 \%$ ). The top five provinces of photovoltaic power generation cumulative capacity in the nation are Gansu, Qinghai, Xinjiang, Ningxia and Inner Mongolia, totally accounted for $79.7 \%$ of the country's photovoltaic power generation capacity.

According to the the latest data released by national energy bureau, by the end of September 2014, The grid capacity of national photovoltaic power station is 8.77 million $\mathrm{kW}$ while the distributed photovoltaic 4.44 million $\mathrm{kW}$ cumulatively. Within the operating scope of State grid companies, The grid capacity of photovoltaic power station and distributed photovoltaic will be increased by 2.05 million $\mathrm{kW}$ and 1.15 million $\mathrm{kW}$ respectively, which is expected the new scale is about 1,0 million $\mathrm{kW}$. From these data, photovoltaic power generation capacity in China recent years is in rapid growth recent years.

And, of course, in addition to generating capacity, what people care more about is the cost of photovoltaic power generation. Through photovoltaic power generation feedin tariff in the table 1 recently, we predict the future feedin tariffs. 
TABLE I : CHINESE PHOTOVOLTAIC POWER GENERATION COST AND PREDICT (UNIT: YUAN/KWH)

\begin{tabular}{|c|l|l|l|l|l|}
\hline $\begin{array}{l}\text { Effective } \\
\text { hours }\end{array}$ & 2006 & 2010 & 2014 & 2015 & 2020 \\
\hline 1000 & 5.5 & 3.6 & 1.8 & 1.6 & 0.9 \\
\hline 1100 & 5.0 & 3.3 & 1.7 & 1.4 & 0.8 \\
\hline 1200 & 4.6 & 3.0 & 1.6 & 1.2 & 0.8 \\
\hline 1300 & 4.2 & 2.8 & 1.4 & 0.9 & 0.7 \\
\hline 1400 & 3.9 & 2.6 & 1.2 & 0.9 & 0.7 \\
\hline 1500 & 3.7 & 2.4 & 0.9 & 0.8 & 0.6 \\
\hline
\end{tabular}

It can be seen from the table above that cost will reduce gradually, until in 2020, we forecast can achieve parity with photovoltaic surf the Internet.

\section{IMPROVEMENTS OF SOLAR PHOTOVOLTAIC POWER GENERATION IN CHINA}

Although in recent years China's photovoltaic power generation has entered the track of rapid development, but in the process of the implementation of photovoltaic power generation ,China still has many deficiencies, which limits the development of photovoltaic power generation.so we need make improvements.

\section{A. enhance the independent innovation ability}

In the cost of photovoltaic power generation system, solar cells have the highest cost. As for the development of new type of solar cell in China is lagged far behind with other countries, $95 \%$ of silicon raw materials of photovoltaic products mainly rely on import, which is very adverse to the development of photovoltaic industry in our country. The implementation of commercialization of solar cells is still a long way to run. We can improve the ability of independent innovation and reduce the cost of solar cells, which can reduce the overall cost of photovoltaic power generation.

\section{B. expand the domestic market}

Because photovoltaic power generation in China starts late and develops slowly, our country's photovoltaic products are $95 \%$ sells to foreign countries.People even don't know photovoltaic products ,just thinking photovoltaic products is very expensive. Now the cost of photovoltaic products has been reduced, we should issue a corresponding policy that promotes the photovoltaic power generation to let people know photovoltaic products .People shuold know photovoltaic energy is a clean energy, can effectively solve the problem of carbon emissions and pollution. So expanding the domestic market is necessary.

\section{C. reduce the unit cost}

The important reason for the slow development of photovoltaic power generation is the high cost of electricity. Unit power generation cost of photovoltaic power generation is several times higher than thermal power generation. Although having been greatly reduced after government subsidies, the cost of domestic large distributed power generation project has dropped to 0.8 yuan/KWH in China. But on the whole, the cost of photovoltaic power generation remains stubbornly high, which still needs to reduce the cost, large area as soon as possible to achieve parity with the Internet.

\section{THE APPLICATION OF PHOTOVOLTAIC POWER GENERATION}

\section{A. the application of grid photovoltaic power station}

There are abundant solar energy resources and also sparsely populated in western China.So it's great to establish large grid photovoltaic power station in the place which is not suitable for cultivation of crops such as the desert .By doing that,we can not only make full use of land resources, but also promote the development of local economy. To tie in with the development of the western region, the Chinese government has implemented the "sunshine project", "sail plan" and "bright project", etc.

\section{B. The application of off-grid photovoltaic power plant}

Because the power grid can't cover rural and remote areas, we can strengthen the building of off-grid photovoltaic power station in the rural and remote areas. Construction of off-grid photovoltaic power station can not only save the higher cost of the power network, and can also solve the problem of areas without electricity, so it is one of the main way of photovoltaic power generation applications for our country government.

\section{C. solar building integration}

In China's eastern and central parts, the cities are more concentrated, whose economy is more developed and power consumption is big.In those areas photovoltaic power generation is in big demand, but land resources are scarce, There are no place for the construction of large grid photovoltaic power station. With the maturity and development of Building Integrated Photovoltaic technology, a growing number of photovoltaic power generation system can make use of the roof, structures and facade of the buildings, will gradually overcome the lack of covering an large area . In the $<<$ In the long-term development of renewable energy $>>$ it is put forward that our country hopes to install 20000 sets of photovoltaic building by2020, cumulatively installed 1 million kilowatts.

\section{D. solar electronic products}

Now there are all kinds of solar products in the market, such as solar street lights and solar lawn plant and other kind of solar daily electronic products, It's great that cost is low,which can undertake large-scale promotion. That is to say, this kind of product has a very big market.

\section{REFERENCES}

[1] Hanyun.H,The principle of solar photovoltaic power generation applications, Chemical Industry Press, 2009.

[2] Jiang,L.P.,"Pvof China- 2014 and the future development",Beijing::Electric Age,2015.

[3] Newspaper's editorial office,"China's energy development new trend,Beijing:North China Electric Power”, 2014.

[4] BP Energy Outlook 2035 http://www.bp.com/content/dam/bp/pdf/Energy-economics/energyoutlook-2015/Energy_Outlook_2035_booklet.pdf,2015.

[5] Li,J.F.,"The development of Chinese pv report", China environmental science press, 2007. 
[6] Gao,Y.X.\&Ma,J., "Solar photovoltaic power generation technology present situation and existing problems of the paper", BeiJing:China Electric Power(Technology Edition), 2012.

[7] Zhou,B.W.,"Solar photovoltaic power generation technology and The development prospect",Haerbin:Technology Innovation And Application,2014.
[8] Hou,D., "The necessity of the development of solar photovoltaic Power generation and technical analysis", Beijing:Practical Electronics,2014.

[9] Zhang,T.Y.\&Tian,Y.,"Analysis of photovoltaic power station in the future development trend", Shijiazhuang:Technology Wind, 2015.

[10] Zhu.Y,"Solar and wind power is everything”Energy Research \& Utilization, 2014. 